\title{
PENGEMBANGAN KARTU DOMINO SEBAGAI MEDIA PEMBELAJARAN KOSAKATA BAGI SISWA KELAS V SEKOLAH DASAR
}

\author{
Atikah Mumpuni* \\ Agus Supriyanto \\ Pendidikan Guru Sekolah Dasar, Fakultas Keguruan dan Ilmu Pendidikan, Universitas Muhadi Setiabudi \\ Jl. Pangeran Diponegoro No.KM.2, Rw. 11, Pesantunan, Brebes, Jawa Tengah, Indonesia \\ *email: atikahmumpuni@umus.ac.id
}

Artikel diterima: 15 Maret 2020; disetujui: 31 Mei 2020

\begin{abstract}
The research was aimed to develop a domino card media that was reasonable and effective in improving Indonesian language mastery for fifth grade students of elementary school. This was a development research that comprised of ten stages. Product in from of a reasonable vocabulary domino card media based on scores obtained form material expert and media expert each with value 80 with a good category. Product effectiveness yielded in improving Indonesian language vocabulary mastery based on a hypothesis test result of sigificance (2-tailed) of 0,034 smaller than 0,05 . That domino card media was effective in improving Indonesian language vocabulary mastery for elementary school students.
\end{abstract}

Keywords: Media; domino; vocabulary; language; elementary school.

\begin{abstract}
Abstrak: Tujuan dari penelitian ini adalah mengembangkan media kartu domino yang layak dan efektif dalam meningkatkan penguasaan kosakata bahasa Indonesia bagi siswa kelas $\mathrm{V}$ Sekolah Dasar. Penelitian ini merupakan penelitian pengembangan, yang terdiri dari sepuluh tahap. Produk yang dihasilkan berupa media kartu domino kosakata yang layak, berdasarkan skor yang diperoleh dari ahli materi dan ahli media, masing-masing dengan nilai 80 dengan kategori baik. Keefektifan produk yang dihasilkan dalam meningkatkan penguasaan kosakata bahasa Indonesia didasarkan pada hasil uji hipotesis diperoleh signifikansi (2-tailed) sebesar 0,034 , lebih kecil dari 0,05. Media kartu domino efektif dalam meningkatkan kemampuan kosakata bahasa Indonesia bagi siswa sekolah dasar.
\end{abstract}

Kata kunci: Media; domino; kosakata; bahasa; sekolah dasar.

Indonesia sebagai negara yang memiliki beragam suku bangsa, tentu memiliki kosakata yang lebih bervariasi. Hal ini diperkuat oleh Soedjito \& Saryono (2011) yang menyebutkan kosakata sebagai kekayaan kata yang dimiliki oleh suatu bangsa. Indonesia merupakan negara yang memiliki kekayaan bahasa yang digunakan dalam keseharian berbagai suku bangsa yang ada di 
Indonesia. Sekitar $12 \%$ bahasa yang ada di dunia berada di Indonesia (Sobarna, 2010). Kekayaan bahasa ini juga didukung dengan kekayaan kosakata yang ada dalam Bahasa Indonesia.

Bahasa Indonesia memiliki ratusan ribu kosakata, namun masih sedikit dari kosakata ini yang sering digunakan dalam berbahasa. Kosakata harus dikuasai oleh siswa agar dapat memahami informasi yang didapatkan baik lisan maupun tulisan. Penguasaan kosakata juga akan mendukung kegiatan siswa dalam mengemukakan pendapat, serta mengutarakan maksud dan tujuan. Dengan demikian, kosakata adalah unsur dasar yang harus dikuasai seorang siswa sebelum mempelajari suatu bahasa (Wiyanti, 2015; Sunariati, dkk., 2019).

Penguasaan kosakata bahasa Indonesia, dapat diketahui dari indikator-indikator yang terkait. Firman, dkk., (2019) mengemukakan indikator penguasaan kosakata di Indonesia ada lima unsur yaitu, penguasaan makna, afiksasi, kelas kata, bentuk kata baku, dan bentuk tidak baku. Sinonim dan antonim sendiri dalam penelitian ini masuk dalam salah satu unsur tersebut, yaitu penguasaan makna. Kosakata bahasa Indonesia itu sendiri sering kali dianggap sebagai hal yang mudah karena tulisan dan cara membacanya kebanyakan sama. Disamping itu, kosakata bahasa Indonesia dianggap sudah biasa diterapkan dalam kegiatan berbahasa sehari-hari, sehingga anak dianggap sudah memahaminya secara otomatis. Hal ini tentu berdampak pada kurang diperhatikannya pembelajaran kosakata bahasa Indonesia, khususnya di Sekolah Dasar.

Kurang diperhatikannya pembelajaran kosakata dapat dilihat salah satunya dengan tidak digunakannya media dalam proses pembelajaran kosakata. Kosakata bahasa Indonesia tentu sama seperti materi pembelajaran yang lainnya di Sekolah Dasar, memerlukan media yang dapat menunjang proses pembelajaran. Risky (2019) menyebutkan media dapat menumbuhkan perhatian dan menambah kemudahan siswa dalam mempelajari materi pelajaran, termasuk materi kosakata bahasa Indonesia.

Media kartu adalah salah satu media yang dapat digunakan dalam pembelajaran di Sekolah Dasar. Pada muatan bahasa Indonesia, khususnya di kelas rendah, media kartu dapat digunakan sebagai media dalam pembelajaran membaca. Rumidjan, dkk., (2017) dalam hasil penelitiannya menyebutkan bahwa media kartu dapat meningkatkan keterampilan membaca siswa. Penggunaan media kartu yang lebih bervariasi di kelas tinggi, khusunya penggunaan kartu domino, banyak diterapkan dimuatan pelajaran yang lain, seperti muatan matematika. Aprinawati (2017) menunjukkan bahwa penggunaan kartu domino telah terbukti efektif dalam meningkatkan hasil belajar matematika siswa kelas V Sekolah Dasar. Sejauh ini belum ada penelitian tentang pengembangan kartu domino yang digunakan meningkatkan penguasaan kosakata bahasa Indonesia di Sekolah Dasar.

Hasil observasi awal di SD Negeri 01 Sudagaran menunjukkan kurang diperhatikannya pembelajaran kosakata. Hal ini dapat dilihat dengan tidak digunakannya media pembelajaran 
untuk materi kosakata bahasa Indonesia. Dengan tidak diperhatikannya pembelajaran kosakata, mengakibatkan siswa kelas $\mathrm{V}$ di sekolah tersebut mengalami kesulitan dalam memaknai isi teks bacaan, menentukan gagasan pokok dan penjelas, dan menentukan pesan yang terkandung dari suatu karya sastra. Disamping itu, siswa juga kesulitan dalam menceritakan suatu hal baik secara lisan maupun tulisan. Oleh sebab itu, penelitian ini bertujuan untuk mengembangkan media kartu domino kosakata yang layak dan efektif bagi siswa kelas V di SD Negeri 01 Sudagaran.

\section{METODE}

Penelitian ini merupakan penelitian pengembangan yang dilaksanakan dalam jangka waktu 4 bulan, dimulai dari bulan November 2019 sampai dengan bulan Februari 2020. Prosedur penelitian pengembangan yang dilakukan, merujuk pada pendapat Borg, dkk., (2003) meliputi: 1) pengumpulan informasi; 2) perencanaan; 3) pengembangan draf produk; 4) uji coba awal; 5) revisi hasil uji coba; 6) uji coba lapangan; 7) menyempurnakan produk hasil uji coba lapangan; 8) uji coba lapangan operasional; 9) penyempurnaan produk akhir; 10) desiminasi dan implementasi. Mengingat keterbatasan waktu penelitian, penelitian pengembangan ini dilaksanakan sampai pada tahap kesembilan, yaitu penyempurnaan produk akhir.

Penelitian ini dilaksanakan di kelas V SD Negeri 01 Sudagaran dan SD Negeri 02 Sudagaran. Setelah dilakukan pengumpulan informasi, perencanaan, dan pengembangan draf produk, dilakukan tahap uji coba. Pada tahap uji coba awal, kartu domino kosakata diujicobakan pada empat orang siswa kelas V SD Negeri 01 Sudagaran yang dipilih secara acak. Selanjutnya, pada tahap uji coba lapangan, kartu domino yang telah direvisi dari masukan saat uji coba awal, kembali diujicobakan pada 10 orang siswa kelas V SD Negeri 01 Sudagaran. Kesepuluh siswa tersebut adalah selain sampel siswa pada saat uji coba awal. Terakhir, tahap uji coba lapangan operasional, kartu domino kosakata yang telah direvisi, diujicobakan pada sampel yang lebih banyak, yaitu sebanyak 24 orang siswa SD Negeri 01 Sudagaran selain sampel uji coba awal dan uji coba lapangan.

Guna mengetahui keefektifan produk dalam meningkatkan kosakata Bahasa Indonesia, maka sampel uji coba lapangan operasional sebanyak 24 siswa tersebut yang selanjutnya disebut sebagai kelas eksperimen akan dibandingkan dengan kelas kontrol. Kelas kontrol berjumlah 20 orang siswa kelas V SD Negeri 02 Sudagaran. Kelas eksperimen yaitu kelas yang mendapat perlakuan berupa media kartu domino sedangkan kelas kontrol adalah kelas yang tidak mendapat perlakuan.

Instrumen yang digunakan dalam penelitian ini adalah tes dan angket jenis skala likert. Teknik pengumpulan data yang digunakan dalam penelitian yaitu tes untuk mengukur kemampuan kosakata siswa dan angket skala likert untuk mengukur kelayakan produk kartu domino yang 
dikembangkan. Adapun kisi-kisi untuk instrumen tes yang digunakan untuk mengukur kemampuan kosakata siswa tersaji dalam Tabel 1.

Pada Tabel 1, dapat diketahui bahwa jumlah soal yang digunakan untuk mengukur kemampuan kosakata siswa, khususnya pada materi antonim dan antonim ada 30 soal. Masingmasing indikator terdapat lima butir soal yang sebelumnya telah diujicobakan terlebih dahulu. Soal tes tersebut disajikan dalam bentuk pilihan ganda.

Tabel 1. Kisi-Kisi Soal Tes Kosakata

\begin{tabular}{lllll}
\hline \multicolumn{1}{c}{ No. } & Aspek Penilaian & & \multicolumn{1}{c}{ Indikator } & Jumlah Soal \\
\hline 1. & Antonim & a. & Mengetahui antonim dari kata yang disajikan & 5 \\
& b. & $\begin{array}{l}\text { Menempatkan kata berantonim yang tepat } \\
\text { dalam kalimat } \\
\end{array}$ \\
& c. & $\begin{array}{l}\text { Menganalisis ketepatan penggunaan antonim } \\
\text { dalam kalimat }\end{array}$ & 5 \\
& Sinonim & a. & Mengetahui sinonim dari kata yang disajikan & 5 \\
& b. & $\begin{array}{l}\text { Menempatkan kata bersinonim yang tepat } \\
\text { dalam kalimat } \\
\end{array}$ \\
& c. & $\begin{array}{l}\text { Menganalisis ketepatan penggunaan sinonim } \\
\text { dalam kalimat }\end{array}$ & 5 \\
& & & 30 \\
\hline Jumlah Soal & & &
\end{tabular}

Selanjutnya kisi-kisi angket kelayakan kartu domino tersaji dalam Tabel 2. Pada Tabel 2, dapat diketahui bahwa jumlah butir pertanyaan yang disajikan untuk mengetahui kelayakan kartu Domino Kosakata adalah sebanyak 15 butir pernyataan. Dalam pengembangan produk uji kelayakan kartu domino kosakata dilakukan secara terpisah antara uji kelayakan materi dan uji kelayakan media. Sementara dalam tahap uji coba produk, uji kelayakan dilakukan secara keseluruhan. Disamping itu, dalam angket juga ditambahkan pertanyaan terbuka agar responden dapat memberikan masukan terkait produk yang dikembangkan.

Tabel 2. Kisi-Kisi Angket Kelayakan Kartu Domino Kosakata

\begin{tabular}{|c|c|c|c|}
\hline No. & Aspek Penilaian & Indikator & $\begin{array}{c}\text { Butir } \\
\text { Pernyataan }\end{array}$ \\
\hline \multirow[t]{3}{*}{1.} & Kelayakan Materi & $\begin{array}{ll}\text { a. } & \text { Kesesuaian materi dengan tujuan }\end{array}$ & 2 \\
\hline & & b. Kesesuaian cakupan materi & 2 \\
\hline & & c. Kejelasan materi dan bahasa pada media & 2 \\
\hline \multirow[t]{4}{*}{2.} & Kelayakan Media & a. $\quad$ Tampilan & 2 \\
\hline & & b. Penggunaan Teks & 2 \\
\hline & & c. Penyajian (susunan) & 2 \\
\hline & & d. Efektifitas & 3 \\
\hline \multicolumn{3}{|c|}{ Jumlah Soal } & 15 \\
\hline
\end{tabular}

Teknik analisis data dalam penelitian ini ada dua yaitu data kualitatif dan kuantitatif. Teknik kualitatif dilakukan untuk mendesripsikan kelayakan produk kartu domino kosakata yang dikembangkan. Sementara, teknik kuantitatif digunakan untuk menghitung keefektifan produk kartu domino yang dikembangkan, melalui uji t dengan berbantuan SPSS. 


\section{HASIL DAN PEMBAHASAN}

\section{Hasil Pengembangan Produk Awal}

Produk awal yang dikembangkan berupa kartu domino kosakata yang didesain dengan spesifikasi yang telah ditentukan. Rancangan awal produk media kartu domino kosakata terdiri dari 28 kartu, dibuat tanpa ada warna, hanya berisi tulisan yang mengandung pasangan sinonim dan antonim. Kotak-kotak yang kosong merupakan kotak ajaib, seperti dalam kartu domino aslinya, yang dapat diletakkan secara bebas ketika permainan berlangsung. Adapun rancangan produk awal yang telah dibuat ditunjukkan pada Gambar 1.

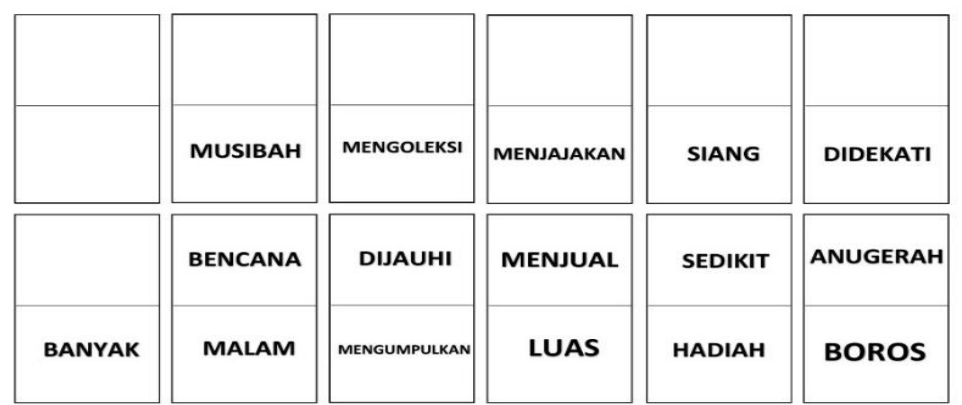

\section{Gambar 1. Contoh Rancangan Produk Awal Media Kartu Domino Kosakata}

Rancangan produk awal ini, kemudian dinilai oleh ahli materi, yaitu ahli bahasa dan ahli media. Pada pengembangan media kartu domino kosakata ini, kriteria penilaian dari ahli materi dan ahli media disesuaikan dengan karakteristik media. Kriteria penilaian serta hasil penilaian yang diperoleh dari ahli materi disajikan dalam Tabel 3.

\section{Tabel 3. Penilaian Ahli Materi untuk Rancangan Produk Awal Media Kartu Domino Kosakata}

\begin{tabular}{llcc}
\hline No. & \multicolumn{1}{c}{ Kriteria Penilaian } & Skor & Kriteria \\
\hline 1. & Kesesuaian materi dengan tujuan & 25 & Sangat baik \\
2. & Kesesuaian cakupan materi & 25 & Sangat baik \\
3. & Kejelasan materi dan bahasa pada media & 30 & Baik \\
\hline \multicolumn{4}{c}{ Total Skor }
\end{tabular}

Berdasarkan penilaian dari ahli materi dapat diketahui bahwa penilaian untuk rancangan produk berada pada kategori baik. Adapun masukan dari ahli materi adalah perlu adanya penyederhanaan bahasa pada penulisan aturan main permainan kartu domino kosakata, agar lebih mudah dipahami oleh siswa. Selanjutnya, penilaian dari ahli media terkait rancangan produk yang dikembangkan tersaji pada Tabel 4 sebagai berikut.

Tabel 4. Penilaian Ahli Media untuk Rancangan Produk Awal Media Kartu Domino Kosakata

\begin{tabular}{llcc}
\hline No. & \multicolumn{1}{c}{ Kriteria Penilaian } & Skor & Kriteria \\
\hline 1. & Tampilan & 20 & Baik \\
2. & Penggunaan Teks & 25 & Sangat Baik \\
3. & Penyajian (susunan) & 20 & Baik \\
4. & Efektifitas & 15 & Baik \\
\hline \multicolumn{2}{r}{ Total Skor } & $\mathbf{8 0}$ & \\
\hline
\end{tabular}


Berdasarkan Tabel 4, dapat diketahui bahwa penilaian ahli media untuk rancangan produk awal media kartu domino kosakata sebesar 80, artinya rerata penilaian dari semua aspek adalah baik. Adapun masukan dari ahli media terkait rancangan produk awal media kartu domino kosakata adalah perlunya penambahan warna. Penambahan warna pada kartu akan membantu siswa yang tidak mengetahui sinonim dan antonimnya akan terbantu melalui warna-warna yang digunakan.

\section{Hasil Uji Coba Produk}

Rancangan awal produk media kartu domino kosakata yang sudah diberi masukan oleh ahli materi dan ahli bahasa, kemudian direvisi dan di ujicobakan. Adapun rancangan produk yang telah direvisi dan siap untuk diujicobakan ditunjukkan pada Gambar 2.

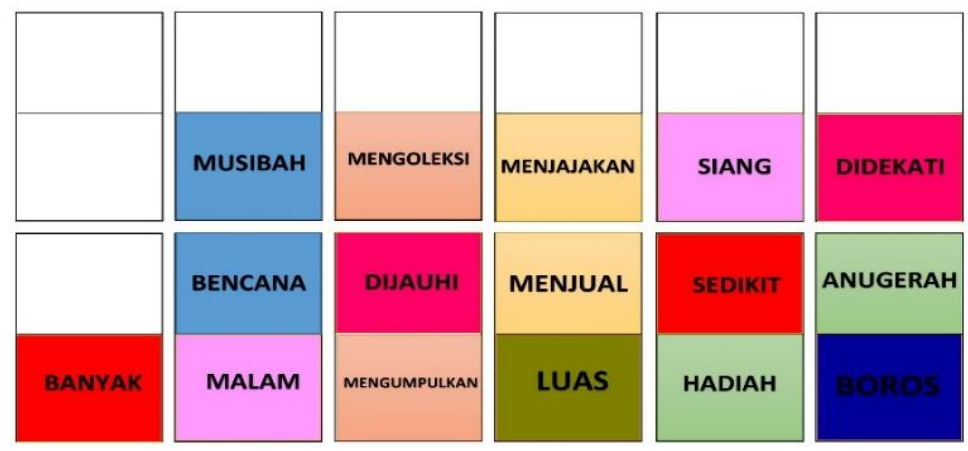

Gambar 2. Contoh Hasil Revisi Rancangan Produk Awal Media Kartu Domino Kosakata

Revisi dilakukan dengan menambahkan warna-warna yang sesuai dengan pasangannya, baik itu untuk sinonim atau antonim. Uji coba dilaksanakan tiga kali, yang meliputi uji coba awal, uji coba lapangan, uji coba lapangan operasional.

\section{Uji Coba Awal}

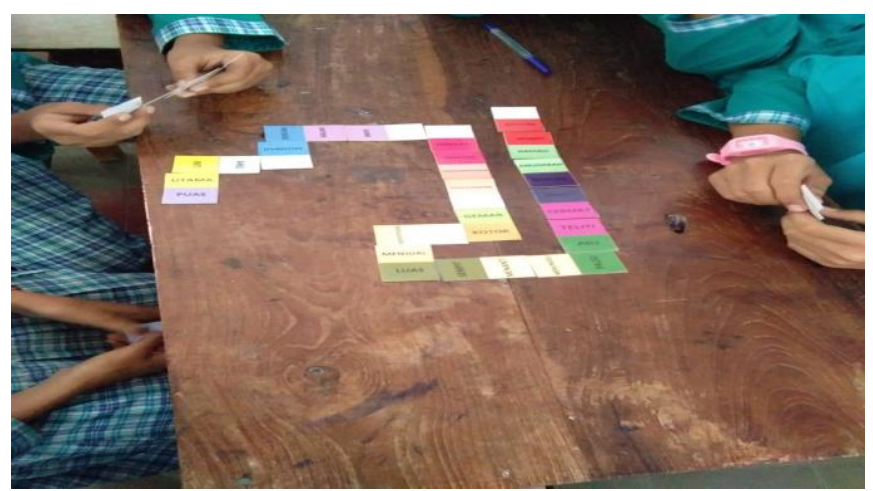

Gambar 3. Subjek Uji Coba Awal Memainkan Kartu Domino Kosakata

Uji coba awal dilakukan terbatas pada empat orang siswa kelas V SD Negeri 01 Sudagaran. Keempat siswa yang dipilih secara acak. Siswa tersebut diminta untuk bermain kartu domino kosakata sesuai dengan petunjuk permainan kartu domino yang telah dituliskan. Selain 
memperhatikan petunjuk permainan, siswa juga diberi arahan terkait permaian kartu domino kosakata tersebut. Contoh keterlibatan siswa dalam uji coba awal ini ditunjukkan pada Gambar 3.

Dari hasil uji coba awal, peneliti mendapat masukan terkait produk kartu domino kosakata yang sedang dikembangkan, yaitu perlu adanya penambahan tanda untuk sinonim dan antonim. Hal ini untuk memudahkan siswa dalam melaksanakan permainan kartu domino kosakata. Selain itu, kotak putih sebagai kotak ajaib dalam kartu domino yang dapat diletakkan dimana saja diberi tulisan sinonim dan antonim.

\section{Uji Coba Lapangan}

Selanjutnya, setalah dilakukan uji coba awal, produk direvisi sesuai dengan masukan dalam uji coba awal. Revisi tersebut meliputi pemberian tanda dalam kosakata yang termasuk sinonim maupun antonim. Pemberian tanda tersebut yaitu dengan memberikan huruf 's' pada kosakata yang diminta dicari sinonimnya, dan memberikan huruf 'a' pada kosakata yang diminta dicari antonimnya. Hasil produk setelah revisi selanjutnya digunakan dalam tahap uji coba. Gambar 4 menunjukkan contoh hasil revisi pada produk kartu domino kosakata.

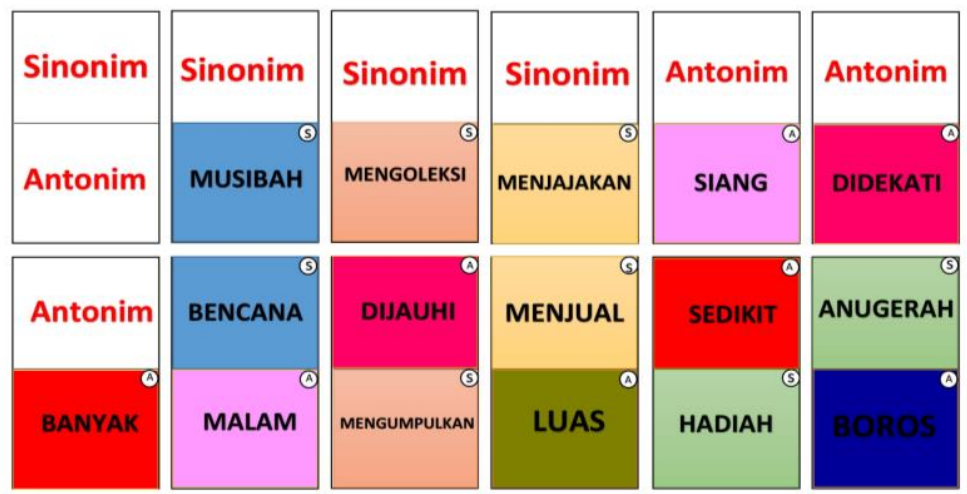

Gambar 4. Contoh Revisi Kartu Domino Kosakata

Produk yang telah diperbaiki tersebut, kemudian diujicobakan pada subjek uji coba lapangan yang berjumlah sepuluh siswa. Subjek uji coba lapangan adalah siswa kelas V SD Negeri 01 Sudagaran tahun ajaran 2019/2020, selain subjek uji coba awal. Dalam pelaksanaan uji coba lapangan ini, kesepuluh orang siswa tersebut dibagi menjadi dua kelompok, masing-masing kelompok terdiri dari lima orang siswa.

Adapun masukan-masukan yang dari hasil uji coba lapangan tersebut yaitu, perlu adanya lembar evaluasi untuk menuliskan sinonim dan antonim yang sudah didapatkan dari permainan tersebut. Hal ini dimaksudkan agar siswa tidak hanya fokus pada permainan, tetapi juga dapat menguasai kosakata seperti tujuan pembelajaran.

\section{Uji Coba Lapangan Operasional}

Uji coba lapangan operasional dilakukan setelah revisi produk berdasarkan masukan dari kegiatan uji coba lapangan. Revisi produk yang dilakukan mencakup aturan main kartu domino 
kosakata. Selanjutnya, setelah subjek uji coba operasional melaksanakan permainan kartu domino kosakata, subjek mengerjakan postes. Postes dilakukan untuk mengetahui sejauh mana keefektifan kartu domino kosakata dalam meningkatkan penguasaan kosakata siswa. Adapun hasil postes pada subjek uji coba lapangan operasional tersaji dalam Tabel 5.

Tabel 5. Tabel Distribusi Frekuensi Hasil Postes Subjek Uji Coba Lapangan Operasional

\begin{tabular}{ccc}
\hline No. & Data Nilai & Frekuensi \\
\hline 1. & $15-16$ & 2 \\
2. & $17-18$ & 2 \\
3. & $19-20$ & 3 \\
4. & $21-22$ & 8 \\
5. & $23-24$ & 3 \\
6. & $25-26$ & 3 \\
7. & $27-28$ & 2 \\
\hline
\end{tabular}

Selain subjek uji coba lapangan operasional, postes juga diberikan pada kelas kontrol. Hal ini dilakukan agar data terkait keefektifan kartu domino kosakata terhadap penguasaan kosakata bahasa Indonesia siswa Sekolah Dasar dapat dianalisis. Adapun hasil postes di kelas kontrol tersaji dalam Tabel 6.

Tabel 6. Tabel Distribusi Frekuensi Hasil Postes Kelas Kontrol

\begin{tabular}{ccc}
\hline No. & Data Nilai & Frekuensi \\
\hline 1. & $14-16$ & 4 \\
2. & $17-19$ & 2 \\
3. & $20-22$ & 10 \\
4. & $23-25$ & 2 \\
5. & $26-28$ & 2 \\
\hline
\end{tabular}

Data yang sudah didapatkan kemudian dilakukan uji hipotesis untuk mengetahui keefektifan media kartu domino kosakata terhadap penguasaan kosakata. Sebelum dilakukan uji hipotesis, dilakukan uji prasyarat hipotesis terlebih dahulu. Uji prasyarat hipotesis meliputi uji homogenitas dan uji normalitas. Adapun hasil uji prasyarat hipotesis tersaji dalam Tabel 7 dan Tabel 8.

Tabel 7. Hasil Uji Homogenitas

\begin{tabular}{cccc}
\hline Levene Statistic & df1 & df2 & Sig. \\
\hline 0.017 & 1 & 42 & 0.897 \\
\hline
\end{tabular}

Berdasarkan Tabel 7 diketahui signifikansi yang diperoleh sebesar 0,897. Hal ini berarti taraf signifikansi yang diperoleh lebih dari 0,05. Artinya kedua data adalah homogen. Sementara itu, berdasarkan Tabel 8 dapat diketahui signifikansi pada shaprio-wilk sebesar 0,199. Hal ini berarti taraf signifikansi yang diperoleh lebih dari 0,05. Artinya, kedua data berdistribusi normal.

Tabel 8. Hasil Uji Normalitas

\begin{tabular}{|c|c|c|c|c|c|c|}
\hline & \multicolumn{3}{|c|}{ Kolmogorov-Smirnov $^{a}$} & \multicolumn{3}{|c|}{ Shapiro-Wilk } \\
\hline & Statistic & $D f$ & Sig. & Statistic & $d f$ & Sig. \\
\hline Hasil & 0.140 & 44 & 0.031 & 0.965 & 44 & 0.199 \\
\hline
\end{tabular}


Setelah kedua data dinyatakan homogen dan berdistribusi normal, selanjutnya dilakukan uji hipotesis. Adapun hasil uji hipotesis tersaji dalam Tabel 9. Berdasarkan hasil uji hipotesis pada Tabel 9, dapat diketahui bahwa taraf signifikansi yang diperoleh sebesar 0,034. Hal ini berarti signifikansi (2-tailed) yang diperoleh kurang dari 0,05. Artinya, Ha diterima dan Ho ditolak. Dengan demikian, dapat disimpulkan bahwa kartu domino kosakata terbukti efektif berpengaruh terhadap penguasaan kosakata bahasa Indonesia siswa kelas V Sekolah Dasar.

Tabel 9. Hasil Uji Hipotesis

\begin{tabular}{|c|c|c|c|c|c|c|c|c|c|c|}
\hline & & \multicolumn{2}{|c|}{$\begin{array}{c}\text { Levene's Test } \\
\text { for Equality of } \\
\text { Variances }\end{array}$} & \multicolumn{7}{|c|}{ t-test for Equality of Means } \\
\hline & & \multirow[t]{2}{*}{$F$} & \multirow[t]{2}{*}{ Sig. } & \multirow[t]{2}{*}{$T$} & \multirow[t]{2}{*}{$D f$} & \multirow[t]{2}{*}{$\begin{array}{l}\text { Sig. }(2- \\
\text { tailed })\end{array}$} & \multirow[t]{2}{*}{$\begin{array}{c}\text { Mean } \\
\text { Difference }\end{array}$} & \multirow[t]{2}{*}{$\begin{array}{l}\text { Std. Error } \\
\text { Difference }\end{array}$} & \multicolumn{2}{|c|}{$\begin{array}{l}95 \% \text { Confidence } \\
\text { Interval of the } \\
\text { Difference }\end{array}$} \\
\hline & & & & & & & & & Lower & Upper \\
\hline \multirow{2}{*}{ Hasil } & $\begin{array}{l}\text { Equal } \\
\text { variances } \\
\text { assumed }\end{array}$ & 0.017 & 0.897 & 2.195 & 42 & 0.034 & 2.375 & 1.082 & 0.191 & 4.559 \\
\hline & $\begin{array}{l}\text { Equal } \\
\text { variances } \\
\text { not assumed }\end{array}$ & & & 2.187 & 39.919 & 0.035 & 2.375 & 1.086 & 0.180 & 4.570 \\
\hline
\end{tabular}

\section{Revisi Produk Akhir}

Produk akhir sebagai hasil penelitian ini adalah paket kartu domino kosakata bahasa Indonesia. Adapun produk akhir yang telah disempurnakan setelah melewati uji coba awal, uji coba lapangan, dan uji coba lapangan operasional meliputi: 1) kartu domino kosakata (sinonimantonim) bahasa Indonesia; 2) petunjuk permainan kartu domino kosakata; dan 3) lembar yang digunakan untuk menulis sinonim dan antonim yang didapatkan dari permainan domino kosakata.

Kartu domino kosakata (sinonim-antonim) bahasa Indonesia sebagai produk penelitian, masih sama seperti kartu domino pada saat uji coba lapangan operasional. Adapun kartu domino kosakata sebagai produk hasil penelitian ini tersaji pada Gambar 5. Kartu domino kosakata sebagai produk hasil penelitian ini memiliki pasangan yang sama baik sinonim maupun antonimnya. Selain itu setiap kartu domino juga ditandai dengan tanda sinonim dengan ' $\mathrm{s}$ ' atau antonim dengan'a', di setiap pojok kotak. Hal ini dibuat dengan maksud untuk memudahkan siswa saat bermain kartu domino kosakata sinonim dan antonim. 


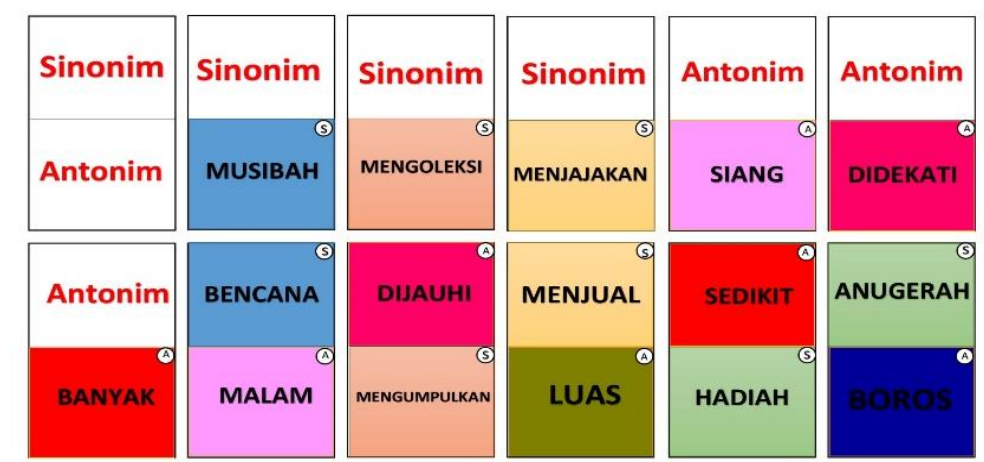

Gambar 5. Contoh Bagian Kartu Domino Produk Akhir Penelitian

Sementara itu untuk petunjuk permainan terdapat revisi pada penyederhanaan serta contoh peletakan kartu. Petunjuk permainan juga dicetak dan dilaminating dengan ukuran yang lebih kecil agar tidak mudah rusak. Pada lembar penulisan sinonim dan antonim yang tadinya berupa lembaran kosong dibuat bertabel. Adapun petunjuk permainan dan lembar penulisan sinonim dan antonim tersaji pada Gambar 6.

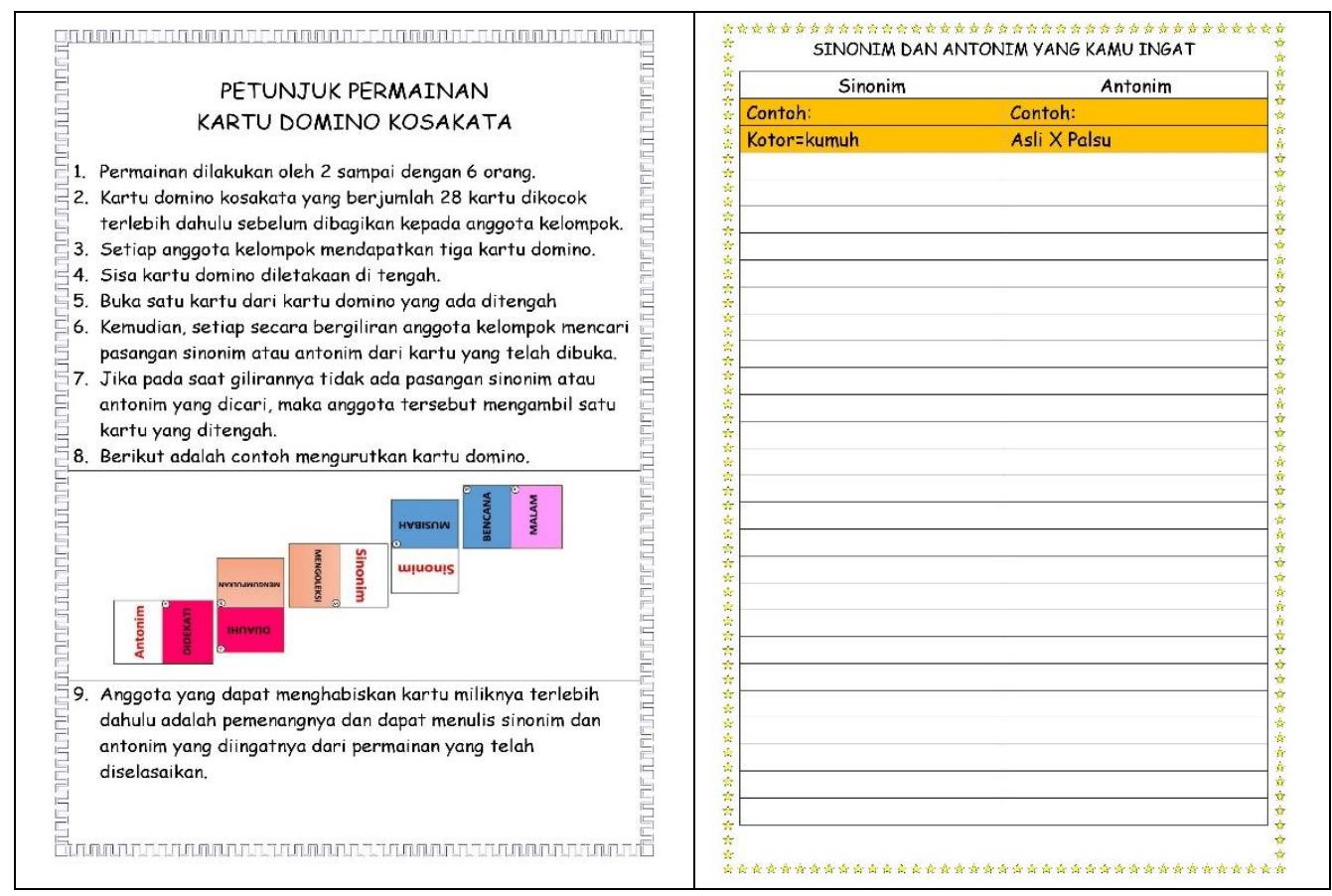

Gambar 6. Aturan Permaian dan Lembar untuk Penulisan Sinonim dan Antonim

Lembar penulisan sinonim dan antonim dicetak pada kertas whiteboard, dengan ukuran A4 agar dapat dihapus dan digunakan kembali pada permainan selanjutnya. Kartu domino, petunjuk permainan, dan lembar penulisan sinonim antonim sebagai produk akhir penelitian kemudian dikemas dalam satu kotak yang menarik. Hal ini dimaksudkan agar permainan tersebut dapat disimpan dan digunakan kembali jika diperlukan.

Selain kelebihan dari media ini, keterbatasan dalam pengembangan produk ini adalah kartu domino sinonim dan antonim hanya dapat memuat beberapa sinonim dan antonim. Sinonim dan 
antonim yang dipilih tentu sinonim dan antonim yang sering digunakan atau sering muncul dalam ujian di Sekolah Dasar. Disamping itu sinonim antonim adalah bagian terkecil dari kosakata. Disamping sinonim antonim, tentu masih banyak cakupan materi kosakata yang lain yang nantinya dapat dikembangkan dalam kartu domino ini.

Media pembelajaran adalah sesuatu yang penting digunakan dalam proses pembelajaran, khususnya di Sekolah Dasar. Hal ini karena, tahap berpikir siswa usia Sekolah Dasar masih dalam tahap operasional konkret. Artinya, siswa memerlukan sesuatu yang konkret untuk membantunya berpikir abstrak. Media dapat dikatakan sebagai jembatan bagi siswa usia Sekolah Dasar untuk dapat membantunya berpikir abstrak.

Media kartu adalah media yang kerap diguanakan dalam pembelajaran bahasa Indonesia. Hal ini sejalan dengan penelitian yang telah dilakukan oleh Rumidjan, dkk., (2017) yang menunjukkan hasil bahwa media kartu dapat digunakan sebagai salah satu alternatif pembelajaran bahasa Indonesia untuk melatih keterampilan berbahasa siswa. Akan tetapi, penggunaan media kartu juga perlu disisipkan sesuatu yang menarik agar dapat mematik motivasi siswa.

Penggunaan media kartu yang dikombinasikan dengan permainan tentu akan lebih menarik, khususnya dalam pembelajaran bahasa Indonesia. Rahayu \& Riska (2018) dalam hasil penelitiannya menyebutkan, media pembelajaran yang menyenangkan dapat memotivasi siswa dalam proses belajar mengajar. Motivasi yang kuat dalam diri siswa saat proses pembelajaran akan membuat siswa memperoleh hasil belajar yang maksimal pula.

Permainan domino adalah salah satu permainan yang dapat dikombinasikan dengan media kartu. Penelitian terdahulu mengenai media kartu domino telah dilakukan oleh Junia (2018), dalam penelitian tersebut kartu domino yang dikembangkan adalah kartu domino bergambar (mimbar) yang memiliki persentase kelayakan sebesar $84 \%$ dan respon yang sangat baik dari siswa dengan persentase sebesar $86 \%$.

Kartu domino kosakata bahasa Indonesia sebagai produk yang dikembangkan dalam penelitian ini, jika dibandingkan dengan penelitian terdahulu memiliki kelemahan dan kelebihan. Adapun kelemahan kartu domino yang dikembangkan tidak memiliki gambar. Kartu ini hanya tersusun atas tulisan-tulisan, sehingga untuk usia siswa Sekolah Dasar, tampilan media masih kurang menarik. Disisi lain, kartu domino yang dikembangkan memiliki warna-warna yang berbeda untuk setiap pasangan sinonim dan antonim. Warna-warna tersebut akan memudahkan siswa menentukan sinonim dan antonim dari sebuah kata yang disajikan.

Terlepas dari kelemahan dan kelebihan kartu domino yang dikembangkan terbukti efektif dalam meningkatkan kemampuan kosakata bahasa Indonesia siswa Sekolah Dasar, khususnya pada materi sinonim dan antonim. Sinonim dan antonim berguna memberikan pilihan kata (diksi) yang memungkinkan seseorang mengekspresikan diri dengan lebih seksama. Hal ini dipertegas 
oleh Tarigan (2011) bahwa sinonim dan antonim tidak hanya menolong untuk menyampaikan gagasan, tetapi juga membantu membuat perbedaan yang tajam dan tepat antara makna kata-kata tersebut.

Peningkatan kemampuan kosakata siswa tersebut tentu dapat menunjang kegiatan berbahasa yang lain bagi siswa. Hal ini sejalan dengan salah satu kesimpulan hasil penelitian Munirah \& Hardian (2016) bahwa terdapat pengaruh antara menggunakan kosakata terhadap kemampuan menulis. Mengingat kosakata adalah dasar dalam kegiatan berbahasa, tentu akan mempengaruhi kemampuan berbahasa lain selain menulis, yaitu menyimak, berbicara, dan membaca, serta bersastra.

Kartu domino kosakata Bahasa Indonesia mengkombinasikan dua hal, yaitu media kartu dan permainan. Permainan bahasa dalam kartu domino memperkuat penguasaan kosakata bahasa Indonesia siswa kelas V SD Negeri 01 Sudagaran. Penguasaan kosakata yang baik, tentu akan menunjang peningkatan keterampilan berbahasa (Wiyanti, 2015; Sunariati, dkk., 2019; Sukoyo, 2013). Hal ini juga diperkuat dengan hasil penelitian Hayatinnupus \& Permatasari (2019) yang menyebutkan bahwa permainan kata dapat meningkatkan keterampilan berbahasa siswa sekolah dasar.

Permainan yang mudah, akan membuat siswa bersemangat menyelesaikan permainan. Hasil penelitian Kristiantari \& Negara (2018) menyebutkan adanya peningkatan keterampilan manipulatif siswa yang signifikan dari sebelum pembelajaran permainan kecil. Dengan kata lain, siswa akan lebih mudah memahami instruksi dalam permainan, sehingga dapat menyelesaikan permainan hingga akhir. Hal demikian, tentu akan membantu siswa mencapai tujuan pembelajaran yang telah dirumuskan. Pada kartu domino kosakata bahasa Indonesia yang dikembangkan diberi warna dan petunjuk yang jelas. Dengan demikian, siswa akan lebih mudah menyelesaikan permainan kartu domino kosakata bahasa Indonesia dan dapat mencapai tujuan yang diharapkan.

\section{SIMPULAN DAN SARAN}

\section{Simpulan}

Simpulan dari kartu domino kosakata sebagai produk dari hasil penelitian ini adalah sebagai berikut. (1) Media pembelajaran kartu domino kosakata yang layak untuk meningkatkan penguasaan kosakata bahasa Indonesia siswa Sekolah Dasar adalah kartu domino dengan petunjuk yang jelas, perpaduan warna untuk setiap pasangan sinonim atau antonim, dan terdapat lembar untuk menulis sinonim dan antonim yang telah didapatkan dari permainan. (2) Media pembelajaran kartu domino kosakata terbukti efektif meningkatkan penguasaan kosakata bahasa Indonesia siswa Sekolah Dasar. Hal ini dibuktikan dengan diperolehnya taraf signifikansi sebesar $0,034<0,05$ yang berarti Ha diterima dan Ho ditolak. Artinya, terdapat perbedaan rata-rata antara 
kelas yang diberikan perlakuan menggunakan media kartu domino kosakata dengan kelas yang tidak diberikan perlakuan. Kelas yang mendapat perlakuan tersebut memiliki penguasaan kosakata yang lebih baik.

\section{Saran}

Saran dari pemanfaatan produk kartu domino kosakata sebagai hasil dari penelitian ini adalah (1) pelaksanaan permainan ini perlu didampingi oleh guru agar siswa dapat memainkan permainan dengan fokus pada pasangan sinonim atau antonimnya, bukan berfokus pada warnawarna yang ada dalam kartu domino tersebut. (2) Pelaksanaan permainan kartu domino kosakata juga harus dimainkan secara bergiliran, jangan sampai permainan hanya dikuasai oleh satu orang, sehingga tidak meninggalkan pesan karakter yang baik bagi diri siswa.

\section{DAFTAR PUSTAKA}

Aprinawati, I. (2017). Penggunaan Media Kartu Domino Bilangan untuk Meningkatkan Hasil Belajar Matematika Siswa Kelas V SD. Jurnal Pelangi. Vol. 9, No. 2, pg. 123-134

Borg, W. R., Gall, M. D., \& Gall J. P. (2003). Educational research: an introduction. New York: Pearson Education. Inc.

Firman A. D., Hastuti, H. B. P., Sukmawati, \& Rahmawati. (2019). Analisis Hubungan Penguasaan Kosakata dan Kemampun Memahami Unsur Intrinsik Cerpen Siswa SMP di Kota Kendari Ranah: Jurnal Kajian Bahasa, 8(1), 123-142

Hayatinnupus \& Permatasari, I. 2019. Penerapan Metode Permainan dalam Peningkatan Keterampilan Membaca Permulaan di Kelas I Sekolah Dasar. Jurnal Sekolah Dasar: Kajian Teori dan Praktik Pendidikan. Vol. 28, No. 1, diakses pada tanggal 4 Februari 2020, http://journal2.um.ac.id/index.php/sd/article/view/4841

Junia, U. A. (2018). Pengembangan Media Mimbar (Domino Bergambar) Materi Keragaman Sosial, Ekonomi, Budaya, Etnis, dan Agama di Indonesi. Jurnal PGSD, 06 (1), 353-362

Kristiantari, M. G. R. \& Negara, I. G. A. O. (2018). Meningkatkan Keterampilan Manipulatif Melalui Pengembangan Model Pembelajaran Modifikasi Permainan Kecil Siswa Sekolah Dasar. Jurnal Sekolah Dasar: Kajian Teori dan Praktik Pendidikan, Vol. 27, No. 2 diakses pada tanggal 10 Februari 2020, http://journal2.um.ac.id/index.php/sd/article/view/4107

Munirah \& Hardian. (2016). Pengaruh Kemampuan Kosakata dan Struktur Kalimat Terhadap Kemampuan Menulis Paragraf Deskripsi Siswa SMA. Jurnal Pendidikan Bahasa dan Sastra, $16(1), 78-87$

Rahayu, W. A. \& Riska, S. Y. (2018). Pengembangan Media Pembelajaran Game Kosakata Bahasa Inggris. Jurnal Cakrawala Pendidikan, 37 (1), 85-95

Risky, S. M. (2019). Analisis Penggunaan Media Video Pada Mata Pelajaran IPA di Sekolah Dasar. Jurnal Sekolah Dasar: Kajian Teori dan Praktik Pendidikan, Vol. 28, No. 2 diakses pada tanggal 2 Februari 2020, http://journal2.um.ac.id/index.php/sd/article/view/5026

Rumidjan, Sumanto, \& Badawi, A. (2017). Pengembangan Media Kartu Kata untuk Melatih Keterampilan Membaca Permulaan Pada Siswa Kelas I SD. Jurnal Sekolah Dasar: Kajian Teori dan Praktik Pendidikan, Vol. 26. No. 1 diakses pada tanggal 2 Februari 2020, http://journal2.um.ac.id/index.php/sd/article/view/1331

Sobarna, C. (2010). Bahasa Sunda Sudah di Ambang Pintu Kematiankah?. Hubs-Asia, 10(1). 
Soedjito \& Saryono, D. (2011). Kosakata Bahasa Indonesia. Malang: Aditya Media Publishing Sukoyo, J. (2013). Hubungan Penguasaan Kosakata dan Minat Membaca dengan Kemampuan Menulis Eksposisi Mahasiswa Program Studi Pendidikan Bahasa dan Sastra Jawa UNNES. Lingua, 9(1), 24-29.

Sunariati, R., Ismawati, E., \& Riyadi, I. (2019). Hubungan Antara Penguasaan Kosakata dan Struktur Kalimat dengan Kemampuan Menulis Karangan Narasi. Jurnal Pendidikan Bahasa, 8(2), 309-329.

Tarigan, H. G. (2011). Pengajaran Kosakata. Bandung: Angkasa

Wiyanti, E. (2015). Peran minat membaca dan penguasaan kosakata terhadap keterampilan berbicara bahasa Indonesia. Deiksis, 6(02), 89-100. 